\title{
Pseudo and Digital Parapraxis in MMORPGs
}

\author{
Marion HAZA \\ Poitiers University, Poitiers, France
}

\begin{abstract}
This communication proposes to study some language processes, similar in literature and videogames: parapraxis and the choice of a pseudo. It will aim to show how the use of a word reveals the intimacy of the subject, just like the autobiographical novel, which gives information about the writer. We would therefore have the presages of a self-writing in the creation, naming and storytelling of the avatar of a videogame player. From the example of a young player of the MMORPG (Massively Multiplayer Online Role Playing Games) networking game Dofus, who we met in consultation, we will see how his avatar "DeadIop" comes from parapraxis and enables the narration of his emotional intimacy. The unconscious elements that led to the creation of the pseudo enabled him to tell his story and grasp some unexplained facets of himself.
\end{abstract}

Keywords: videogames, parapraxis, pseudo, narration

\section{Introduction}

Today, all over the world, teenagers and older people (the average age of players is now 35 years old) play videogames, especially MMORPG (Massively Multiplayer Online Role Playing Games). The addiction concept is often brought up to explain these video games, whereas gamers' identity is rarely questioned. To better understand what is going on with videogames, we will have to think these virtual worlds as a place where people can evolve in as in real life.

This paper proposes to study some elaboration processes, similar in literature and MMORPG videogames, namely parapraxis in the choice of a pseudo and the story of the avatar. The author will show how the use of a word reveals the intimacy of the player-subject, just like the autobiographical novel, which gives information about the writer. We would therefore have the presages of a self-writing in the creation, naming, and storytelling of the avatar of a MMORPG player. From the example of a young player of the MMORPG Dofus, who we met in consultation, we will see how his avatar "DeadIop" comes from parapraxis and enables the narration of his emotional intimacy.

Tom, a young boy of 11 years old in last year of primary school, comes to consult us because of intense sadness and incapacitating anxiety. Tom is a good student, he does not create any problem at home or at school, even if lots of his friends are unruly and always ready for a fight. His mother brings him in because he is embarrassed with a "blood phobia"—as he himself calls it—-that prevents him from attending and listening to science classes, or from watching the news broadcast or some movies. Tom, in such situations, begins to stamp his feet on the floor obsessively, in order to create a bubble of physical stimuli, and is extremely upset. Tom is a withdrawn, sad-looking boy, without visible emotion. He nevertheless lights up when talking on his own of his favorite game, the preteens MMORPG Dofus, a "colorful, amusing, and enchanting” universe. Since a few 
months, Tom has been playing this game, in which he uses several avatars of different levels. In addition to his summoner, his thief, and his mage, Tom commits himself a lot to his main, a warrior avatar of the Iop race. As it is explained in the website's game, "Iops are go-getting warriors beyond reproach! One thing's for sure: Iops really know how to use their weapons. They need to draw first blood at least once a day just to feel alive. Their impetuousness can make Iops the best of knights... and the worst!” (Retrieved from http://www.dofus.com). Tom therefore creates a character capable of major damage, whose violence and link to the blood, that usually really worries Tom, can be detected. Therefore, through the game, Tom transcends his fear. The link to blood of the Iop is valued, and even essential, when it is so costly in Tom's imagination. His "knight, with his huge Mohawk and cross" is called "DeadIop". He explains, during long sessions and without pausing, the battles, fights, quests, and evolutions of his avatar, thus recreating a bloody universe not really threatening.

\section{Pseudo}

Let's begin with questioning the use of the pseudo, inherent to MMORPGs, and sometimes disguise for literary writers.

The pseudo is indeed an integral part of MMORPGs and the construction of the avatar. In the digital world, an avatar refers to any "virtual" character representing a player. It is the intermediary between the subject and the digital space, the extension of oneself, "some kind of technological version of the image returned by a mirror” (Hajji \& Tordo, 2009, p. 659), with all the objective and subjective elements inherent to such an image; it is driven and controlled by its user.

The player invents avatars made of two components: a written one and a graphical one. Nowadays, video games enable to determine in great details all the characteristics of the characters played, from the most basic ones (species, sex, or profession... ), to the most precise ones (skills, biography, pets, relationship status, etc.), as well as all the physical attributes. Players can decide on the physical appearance of their character in an extremely fine way: morphology, facial features, color of the skin, hair, eyes, tattoos, etc..

This way, the players can try out a new sex, love relationships, violent behavior, all in all a whole range of experiences that can be delicate, or even impossible to implement in real life for physiological, psychological, moral or social reasons. "I made a mistake", tells this teenager we met in psychological consultation, on WOW (World of Warcraft), "when I clicked I chose an elf girl. In the end I kept her, she's pretty”. We can interpret this as a misaction and see it as his desire to try out a feminine identity. The practice of MMORPG implies an interpretative dimension of the played role, in the extent that players communicate in writing in the name of their character. To understand properly the identity stake, one has to take into account the relationships "between the players and their own characters, but also the relationships between the players, the characters, and the players with the others' characters” (Di Filippo, 2012, p. 9).

The avatar used online is what enables us to be recognized and distinguished from the others, but it is not in any way what the person identifies to. One does not become one's own avatar: it supports the identity.

It is therefore recommended, when creating a character, before entering the game, to choose a pseudo. Without name, the avatar does not exist. The identity of the player is therefore achieved, after the creation of the physical characteristics of the avatar, through the choice of this pseudo.

For example, we can see with this World of Warcraft player $^{1}$ the use of pseudos: He developed several

${ }^{1} \mathrm{He}$ is the author's patient and told the author that during a psychological consultation in 2012. 
avatars with different functions: "Crowphen", a hunter whose name comes from "Crow" and "Phen” for "Phoenix", because "the crow is a smart animal, capable of lying and of a social behavior, that cleans the campaigns, and the phoenixis reborn from its own ashes. Therefore, the enemy is warned that if he kills him, 'Crowphen' will come back for revenge”. Here we can see the weight of the choice of the pseudo, in its entire aggressive valence. Here are some other characters of our player: As a play on word with another fellow player whose pseudo is "Big", he calls his priest "Bang"; or, as a reference to a member of his family working in science, he creates a warrior called "Watson" to play in duo with "Crick", as a direct reference to the two researchers who discovered DNA. Finally, our player also has a thief called "Nothing" so that the message "You've been killed by 'Nothiiiiing' appears on his opponents' screen”. In this case, the use of the pseudo gives some clues on the character of the player, and, digging somewhat more, on the friendly or family relationships he commits himself to. Nevertheless, without any explication, these elements escape the players' community and may be incorrectly interpreted.

In parallel, in literature, many writers write under a pseudonym, such as Roman Kacew, aka Romain Gary, aka Emile Ajar, who left this suicide note: “I've had a lot of fun. Good-bye, and thank you” (Gary, 1980). Or Philippe Sollers ("clever, ingenious" in latin), whose parents asked to give up on his family name Joyaux, or Françoise Quoirez, minor, who published Bonjour Tristesse (Sagan, 1954) under the pseudo of Sagan, in homage to Marcel Proust; Samuel Clemens, aka Mark Twain, Eric Blair, and aka George Orwell; Richard Bachman, aka Stephen King; Currer Bell, aka Charlotte Brontë, or the writer of Harry Potter; J. K. Rowling, who writes under the pseudonym of Robert Galbraith, etc..

"Why some writers choose to hide behind a pseudonym, whether or not a writer has a real life anyway", asks the writer Paul Auster (1986). This thought can make the link with the question of the real or virtual existence of the avatar. Following the example of Paul Auster, we can ask ourselves: Does the avatar have a real life? Do the naming, thinking, and telling of this figure present and visible on the screen give consistence to the avatar?

\section{Tale of the Avatar-Self}

We can see that beyond the pseudo, the tale and the explanations surrounding the avatar are implicit. Actually, is the tale of the avatar in MMORPGs an autobiography or a fiction?

The creation of a controlled facet of oneself can be found as much in literary writing as in the creation of a digital avatar and its pseudo. The avatar and its generation are indeed "narrative supports" (Tisseron, 2008; Cahn, 2013), and the object of a self-history, just like self-fiction. One way of expressing this self-history that reveals itself in the choice of pseudo and their associated tales corresponds to what Ricœur (Ricoeur) called "narrative identity": Indeed, personal identity brings face to face two uses of the identity concept, the Latin "idem" and "ipse": In its diverse uses, "same" (même) is used in the context of comparison; its contraries are "other”, “contrary”, “distinct”, “diverse”, “unequal”, and "inverse”. The weight of this comparative use of the terme "same" seems so great to me that I shall henceforth take sameness as synonymous with idem-identity and shall oppose to it selfhood (ipseity), understood as ipse-identity. Self-narration is therefore not an invention but a storytelling of reality by organizing events in a readable way: "The specific model of the interconnection of events constituted by employment allows us to integrate with permanence in time what seems to be its contrary in the domain of sameness-identity, namely diversity, variability, discontinuity and instability” (Ricœur, 1996, p. 167). This is how our WOW player can have several identities coexist (warrior, hunter, but also shaman and 
healer), despite the apparent contradiction between the desires and aims inherent to each avatar.

From there, the author will redefine the autobiographical genre.

In autobiography, the author (writer), the narrator ("I"), and the character (protagonist of the story) are one and only person. The events did actually happen; the characters did actually exist; nothing can be invented or fictitious. For Lejeune (2005), it is a "retrospective story in prose that a real person tells of his own existence, laying emphasis on his individual life and, in particular, on the story of his personality" (p. 14). Its distinctive feature is the alternation between story and analysis, that is, the presence of a double look, the writer been looking for elements of his past ego: We got the point of view of the moment, and the remote one, the real time of the story and the time of the enunciation.

Furthermore, autobiography is a relational text: The writer, from the very beginning, by setting the environment, the tone, the relationships, asks the reader to trust him, to believe him, and proposes in exchange to reveal himself. According to Lejeune (2005), we can study the relationship of the narrator to his character (identification, nostalgia, or humor, rejection... ), to himself, to the reader. This reminds the transfer and the link created in the story relation between the MMORPG player and the other who listens to him, psychologist or not, player or not.

Besides, other literary genre that implements narrative identity, self-fiction appeared in 1977 under the pen of Serge Doubrovsky ${ }^{2}$ to refer to his novel Fils (1977). It is a literary genre defined by an "oxymoronic pact" (Jaccomard, 1993, p. 63) or contradictory pact associating two types of opposed narration: like autobiography, it is a story based on the principle of three identities, which nevertheless claims to adhere to fiction in its narrative form. It is a meeting of a real tale of the writer's life and a fictive tale exploring an experience he lived. The names of characters or places may be modified, and the factuality put in the background in favor of an economy of the memory or the narrative choices of the writer. Freed from "inner censorship" (Ernaux, 1992, p. 220), self-fiction leaves a leading place to the expression of the unconscious. Fiction becomes the public tool of an identity quest, "a process that consists in making oneself an imaginary subject by making up adventures" (Vachey, 2001, p. 87).

We can therefore assume that the player, by telling from a first-person perspective the evolution and adventures of his avatar, gets closer to the life story fed by imaginary and fictitious elements. That is what we find in the self-histories/avatars proposed by adolescents in therapy. This construction of one's double leading to identification clearly sets the coexistence of the player, the narrator and the avatar in one and only scene, going from real to virtual life (in the original sense of potential, future). According to John Suler, avatars are just like a Rorschach inkblot; they can convey elements of the conscious and unconscious life of each and every one. By narrating an avatar, we can tell what we are, what we would like to be, what we would have liked to be, what we fear, etc.. The narration and the analysis of game plays, whether oral, written (blogs such as Heyte Nografe's diary, Carnets d'Azeroth (Vachey, 2001, p. 88), forums), or even video (YouTubers), demonstrate this desire (or unconscious necessity) to mend diverse temporalities and aspects of oneself.

\section{Parapraxis}

We propose, to go further, to relate unconscious elements of self-representation, in the story and the choice of the pseudo, through parapraxis.

\footnotetext{
${ }^{2}$ Literary critic and novelist.
} 
Let's be clear about parapraxis. Words are containers that participate in the psychical work of identity elaboration with their manifest and latent content. Words always have a particular meaning for the subject, which can be secret to the others.

In the Dictionary of Psychoanalysis (2007), parapraxis is defined as "an error made in speech (lapsus linguae), writing (lapsus calami), memory (lapsus memoriae) or physical action (lapsus manus)” (p. 98): The subject expresses something else than what initially intended, mainly by substituting an expected term with another word. According to Freud, parapraxis can be considered in two ways: on one hand, in a linguistic conception (Meringer \& Mayer, 1895), parapraxis being heard as disorders resulting from the influence of elements internal to the ongoing speech (influence of other linguistic elements, syllables, words, propositions of the speech); on the other hand, in a psychoanalytical conception, parapraxis being conscious manifestations of unconscious perturbing elements (some kind of compromise resulting from the condensation of two representations, one related to the word we wanted to pronounce, the other related to the disruptive element). It is the free association and the pulling down of censorship barriers that enables one word we do not intend to pronounce to impose itself to the conscience. According to Freud (2004), the interpretation of such a process explains the reason why the parapraxis is often similar to the word we intended to utter. In this perspective, the parapraxis appears, just like every other misaction, as the involuntary expression of a conscious or unconscious intention we do not want to confess, or a repressed idea.

Thinking that the choice of the pseudo, the uses of the avatars and their functions (Tank, Healer, Dps) and the story come from parapraxis enables to take into account the unconscious emotional investment of the player towards his avatar. Digital parapraxis, for example, gives some clues on the inwardness and inner self of the player IRL (In Real Life).

Let's now come back to young Tom and his "DeadIop". Coming from such a sad child, this name raises questions: The author associates, in her counter-transference, on his state of mind, on this unemotional child, almost like a zombie, almost dead, and the author wonders what weights so much upon him. However, not to make hasty interpretations, the author questions him on the creation of the pseudo. That is when Tom explains to the author that he chose this name himself because "Dead" means "Fort" (strong), in order to assert himself in front of his opponents in a powerful position. For the author it is clearly a digital parapraxis, translating unconscious stakes related to Tom's history. When the author explained the meaning of "Dead" as being "Mort" and not "Fort" (parapraxis by sound metonymy revealing unconscious issues), he then associates on his family and some striking memories. In particular the successive illnesses affecting the grandparents (several cerebrovascular accidents, with ensuing motor disability, a dead grandfather and great-grandmother, another grandmother who almost died), and a mother trying to cope with it all, worried and worn out... In particular two traumatic scenes related to him: a foot wound during the Oedipal period that required his mother to "scrape out his foot”, not without pain, and a rabid dog bite he witnessed on TV that impressed him for a long time. Tom can then evoke his sadness as coming from his family, and connects these elements to his blood phobia, wounds, and accidents. "DeadIop" finally comes from a parapraxis that enables him to access a narration of his emotional innermost thoughts. The unconscious elements leading to the creation of the pseudo enabled him to tell his story and to understand some unexplained aspects of his self. Through the tale of the quests and fights of his Iop, he could understand himself and develop his family history. The use of Dofus as a bedtime ritual enabled him to avoid thinking about loss and separation, while keeping on thinking to it, unwittingly, through his "DeadIop" avatar. 


\section{Conclusions}

In conclusion, this paper aims to show how, in MMORPG, the player-subject remains subjected to some unconscious processes (parapraxis/misaction) that escape him and support some rational and conscious choices. The narration of the avatar-self enlightens these processes. It avoids the Violence of Interpretation (Aulagnier, 1975) that can, for example, give a figure of weakness, ghostly, deadly non-existence to “DeadIop”, opposed to his conscious desire of identity, masculine and phallic construction.

\section{References}

Aulagnier, P. (1975). La violence de l'interprétation, du pictogramme à l'énoncé (The violence of interpretation: From pictogram to statement). Paris: PUF.

Auster, P. (1986). The locked room. The New York trilogy. London: Sun and Moon Pr.

Cahn, R., Gutton, P., Tisseron, S., \& Robert, P. (2013). L'ado et son psy (The teenager and his psy). Paris: Editions in Press.

Ciuraru, C. (2001). Nom de plume-A (Secret) History of Pseudonyms. New York: Harper.

Di Filippo, L. (2012). Les notions de personnage-joueur et Roleplay pour l'étude de l'identité dans les MMORPGs (The notions of player-character and role-playing for studyingidentity in MMORPGs). Retrieved from http://www.revue-interrogations.org/Les-notions-de-personnage-joueur

Doubrovsky, S. (1977). Fils. Paris: Gallimard.

Ernaux, A. (1992). Vers un je transpersonnel (Towards a transpersonal I). In Doubrovsky, S., Lecarme, J., \& Lejeune, P. (Eds.), RITM, 6, 219-221.

Freud, S. (2004). Psychopathologie de la vie quotidienne (The psychopathology of everyday life). Paris: Payot.

Gary, R. (1980). Vie et mort d'Émile Ajar (Emile Ajar's Life and death). Paris: Gallimard NRF, Blanche Edition.

Hajji, M., \& Tordo, F. (2009). Avatars et Moi! La fonction psychologique de la multiplicité des avatars dans les jeux video (Avatar and me! Psychological fonction of multiplicity of avatarsin videogames). Adolescence, 27(3), 657-665.

Jaccomard, H. (1993). Lecteur et lecture dans l'autobiographie française contemporaine: Violette Leduc, Françoise d'Eaubonne, Serge Doubrovsky, Marguerite Yourcenar (Reader ans reading in contemporary french autobiography). Genève: Droz.

Laplanche, J., \& Pontalis, J. B. (2007). Vocabulaire de la psychanalyse (Psychoanalysis vocabulary). Paris: PUF Quadrige.

Lejeune, P. (2005). Le pacte autobiographique, Tome 2 (Autobiographicalpact). Paris: Seuil.

Meringer, R., \& Mayer, K. (1895). Versprechen und Verlesen (Slip of the tongue and misreading). Stuttgart: G. J. Göschensche Verlagshandlung.

Ricœur, P. (1996). Soi-même comme un autre (Oneself as another). Paris: Seuil, Point Essais.

Sagan, F. (1954). Bonjour tristesse (Hello sadness). Paris: Juilliard.

Tisseron, S. (2008). Virtuel mon amour. Penser, aimer, souffrir, à l'ère des nouvelles technologies (Virtual my love. Think, love, suffer with new technologies). Paris: A. Michel.

Vachey, F. (2011). Fictions de personnages dans un MMORPG. Entre jeu de rôle et écriture de soi, écrire une persona fiction (Characters' fictions in MMORPGs. Between role plays and self-writing, creating a persona fiction). Sociétés, 3(113), 81-90. 